\title{
Sino-Anglo Code-mixing and Persuasiveness of Chinese Newspaper Advertising: A Sociolinguistic Perspective
}

\author{
Lidan Chen $^{1}$ \\ ${ }^{1}$ School of English for International Business, Guangdong University of Foreign Studies, Guangzhou, China \\ Correspondence: Lidan Chen, School of English for International Business, Guangdong University of Foreign \\ Studies, 2 Baiyun Ave.(N), Baiyun District, GZ 510420, China. E-mail: cld4writing@126.com
}

Received: June 1, 2015 Accepted: June 27, 2015 Online Published: September 29, 2015

doi:10.5539/ijel.v5n5p47 URL: http://dx.doi.org/10.5539/ijel.v5n5p47

This paper is supported by Innovative School Project in Higher Education of Guangdong, China (GWTP-LH-2014-01).

\begin{abstract}
This article sets out to investigate a comprehensive sociolinguistic profile of Sino-Anglo code-mixing in Chinese newspaper advertising in terms of typology and functions. Based on a corpus formed of 603 advertisements from three newspapers in Guangdong province in China, the writer categorizes Sino-Anglo code-mixing in the identified cases into insertional code-mixing and alternational code-mixing, identifies the positioning of mixed English and explores how mixing English into Chinese advertising discourses contributes to persuasiveness of advertising from textual and contextual perspectives by use of Markedness Theory. It is concluded that mixing English into Chinese newspaper advertising is an effective verbal strategy to reach the goal of persuasion by enhancing the semantic, rhetoric and contextual effects. Construction of identity through activation of language schema, screening out the target readers and mitigating the tone with consumers through euphemism are three main contextual functions. To study Sino-Anglo code-mixing can shed light on the understanding of dynamism of language situation in China and the relationship between language and society.
\end{abstract}

Keywords: code-mixing, advertising, persuasiveness, sociolinguistics

\section{Introduction}

In human communication, codes are employed as carriers of information. In some circumstances, especially in bilingual or multilingual speech communities, people use more than one code or mixed codes to communicate with each other. With deepening globalization nowadays, even in a monolingual society, code-mixing is common not only in daily conversations, but also in many other contexts such as job interviews, political speeches and mass media. It is also pervasive in China's newspaper advertising discourses. For instance, advertising slogans like “心动 COOL 号, 最 HIGH 的爱情表白!” (“The most attractive and cool phone number gives you the exciting expression of love!”) and “或许有很多缘分和机会，只是你没有去追寻。Best wishes for you!” (Perhaps there would be lots of opportunities for you to pursue if you didn't give it up. Best wishes for you!') often greet the readers' eyes.

Code-mixing, as a frequent phenomenon in bilingual and multilingual speech communities, more often refers to a mixing of different codes within a sentence and is also called "intrasentential code-switching", while code-switching is reserved for the alternation of codes across sentence boundaries (Myers-Scotton, 1989; Bokamba, 1989; Wardhaugh, 2000). Muysken (2000) regards "code-switching" as "a rapid succession of several languages in a single speech event" and puts the emphasis on the dynamic process of the alternation of codes in oral communication, with the topic being possibly changed or not changed, while code-mixing is a switch of codes within a simple utterance without any associated topic change. The present article employs code-mixing as a cover term for all the phenomena that lexical items and other grammatical features of different codes co-occur in a discourse since a vast majority of the cases from the data are found to be intrasentential without any change of topic.

The mixing of two codes by itself follows certain patterns, and reveals interesting implications that are quite different from those obtained from the study of natural conversations. It is because while 'conversational 
language switching patterns...seem to be beyond the conscious control of individual speakers and often even contrary to their expressed language attitudes' (Fasold, 1984, p. 206), mixing a foreign code in advertising is deliberate and intentional. Advertising discourse differs greatly from non-persuasive varieties mostly in that copywriters adopt all types of strategies to persuade the audience to buy the products advertised or at least impress them and make them bear the brand names in mind. "Persuasiveness refers to the function of drawing the attention of the audience and arousing the interests of them in favor of goods and services and urging them to take action to buy. In order to achieve this aim, the strategies adopted concern verbal messages and pictures (Verstergaard \& SchrØder, 1995, pp. 14-48). Mixing a foreign code is one of the verbal strategies. The study of "persuasiveness" of advertising language in this article is the study of how copywriters use code choice to help to reach this goal.

\section{Literature Review}

\subsection{Oversea Studies of Mixing English in Non-Anglophone Advertising}

Code-mixing has become a common practice in advertising, and there is a lot of oversea literature in this regard.

Haarmann (1984) explored the mixing of several European languages like English, French, German, Italian, and Latin into Japanese advertising, with a view to unveil the advertisers' attempt to associate the advertised merchandise with an ethno-cultural stereotype about the speakers of the given language. Later in his research (Haarmann, 1985, pp. 109) on bilingualism in Japanese writing, he stated that, " the use of a foreign language is not intended to act as a means of verbal communication, but rather to provide the Japanese readership with a certain language requisite to appeal to people's emotion". Bhatia (1987,1992), after studying English in Hindi and European print advertisements and rural Indian advertising, showed that language mixing in advertising is not only motivated by formal or stylistic considerations but is also for their special appeal to the readers because of the beliefs they are associated with. For instance, English serves as a symbol of modern style and high technology, Sanskrit of a deeply rooted culture and tradition, Persian of royalty and luxury, and Hindi, the local language, of a shared social identity. Piller (2001, p. 164), who investigated mixing English in German television and print advertising held that since English is the language of international communication, very few of the advertisements that use English are explicitly oriented toward specific English-speaking countries, but contribute to a social stereotype - cosmopolitan identity for the merchandise in most cases. Martin, in her PhD dissertation (1998), summarized the image of America in France through an analysis of French advertising. Her later study (2002) proved that the discourse domains of English in non-Anglophone advertising differ from those of the English used in other contexts and identifies a cline of code-mixing of six categories in advertising according to the proportion of mixed English in French advertising. She also explored the socio-psycholinguistic effects of different categories in view of the linguistic features of advertising language.

In sum, most of the oversea research covers the mixing of different codes in different sociolinguistic backgrounds and elaborate on the ethno-cultural and psychological motivations as well as the structural patterns of code-mixing in advertising. Since every country are different in the linguistic context, it is essential to review the literature concerning the mixing of English in Chinese advertising in China.

\subsection{Domestic Studies of the Mixing English in Chinese Advertising}

Some researchers (Chan, 1993; Li, 1996, 2000; Luke, 1984, 1992, quoted from Li, D. C. S., 2000, pp. 305-308) in Hong Kong have made great contributions in introducing new theories on Sino-Anglo code-mixing and exploring Hong Kong's bilingual and multilingual phenomena, almost all of which focus on Cantonese-English code-mixing. Other Chinese researchers (He, 1992; Yu, 2001) have studied Sino-Anglo code-mixing in different registers, but little attention has been paid to Sino-Anlgo code-mixing in advertising. Huang (2001) and Lü, Huang \& Wang (2003) explored the mixing of three codes-Mandarin Chinese, English and Cantonese into Chinese print advertising. With regard to Sino-Anglo code-mixing in advertising, he categorized the data into alternational and insertional code-mixing and probed into the motivations for mixing English in Chinese advertising, i.e. to meet the needs of most consumers who are westernized and to discriminate readers with high English proficiency from those with lower English proficiency. Ye \& Qin (2004) carried out a quantitative study of Sino-Anglo code-mixing in print advertising around Guangzhou. Based upon the analysis of 4752 advertisements from the three periods, they generalized the trend of code-mixing in different categories of advertisements and offered the patterns and the causes of such a phenomenon. Their contribution is to present the distribution of code-mixing for different categories of advertisements. Yang (2008) explores the pragmatic meaning of code-mixing in advertising language. Wang (2013) investigated a corpus of 300 advertisements with mix codes from popular newspaper, based on the theory of Markedness Model and found that the English codes syntactically fall into phrases, clauses and letters and that "e", "spa", and "PK" are the most frequently used 
English codes. Besides informing its target consumers of their goods or services, these codes play the socio-pragmatic functions by making the ads vogue, elegant, innovative, and eye-catching.

It is found that, as for Sino-Anglo code-mixing in Chinese advertising, there are still a lot to be explored based on the literature. Some foreign literature can be used for reference in Chinese co text. Firstly, the functional analysis from the sociolinguistic perspective could be further developed through a deeper and more systematical analysis with a view of the sociolinguistic context of China. Secondly, it is possible that the lexical-grammatical pattern is somewhat related to the function. To be more specific, certain pattern of code-mixing in certain category of advertising claims certain function, which has not been explored by the previous researchers. Lastly, position of English in different parts of an advertisement could have some implications that they have not probed. (Note 1)

\section{Research Questions, Method and Data}

\subsection{Research Questions}

Based on the literature, author proposes the following research questions:

1) What are the lexical-grammatical patterns of Sino-Anglo code-mixing in Chinese advertising? Which pattern occurs most frequently? Why?

2) What are the functions of Sino-Anglo code-mixing in Chinese advertising from a comprehensive sociolinguistic perspective?

3) Do different positions of mixed English in Chinese advertising discourses have different implications?

\subsection{Research Method and Data}

The writer collects 603 advertisements of different categories with Sino-Anglo code-mixing in three leading newspapers in Guangdong province-Guangzhou Daily, Yangcheng Evening News and Shenzhen Economic Daily. In the first step, she generalizes the lexical-grammatical patterns of Sino-Anglo code-mixing in Chinese. In the description of typology, a rough distribution of each type and a distribution of mixed English in different part of an advertisement are also presented; and then the writer explores the functions of Sino-Anglo code-mixing inclusive of textual and contextual aspects. The unit of analysis is a single piece of advertising discourse. The writer holds that code-mixing cannot be adequately analyzed with only one approach. So in this article, the writer constructs a comprehensive framework to show a deeper insight into functions.

\section{Pattern Analysis}

\subsection{Muysken's Model for Taxonomy}

Based on two structural analyses - the Matrix Language Frame Model of Myers-Scotton (1993a) and Equivalence and Free Morpheme Constraint proposed by Poplack (2000), Muysken (2000, pp. 3) accounts for three patterns found in terms of general properties of grammar or different processes of mixing:

- Insertion of the material (lexical items or entire constituents) from one language into a structure of the other language ;

- Alternation between structures of different languages ;

- Congruent lexicalization of material from different lexical inventories into a shared grammatical structure.

And as for insertion, according to Myers-Scotton, code-mixing takes places within a frame set by the matrix language or the base language, in which an alien lexical or other linguistic constituent is inserted. And as for the identification of matrix language, Myers-Scotton (1993a, p. 60) said, "The matrix language is generally the language in which speakers have the higher proficiency" and "the matrix language is generally the more unmarked choice".

\subsection{Data Analysis}

All the cases identified from the data can be put into two categories, insertion and alternation, since no shared grammatical structures can be found from Chinese and English discourse in the collected data.

\subsubsection{Insertion}

In most cases, Chinese serves as the matrix language, with English as the embedded language. It is Chinese that projects the morph-syntactic frame for the entire sentence. Only in very few want ads is English the matrix language.

And the inserted English item could be a letter, a word, a phrase, a clause which is usually a short idiom, and 
even a discourse. Therefore, the insertional code-mixing could be subdivided into letter insertion, word and phrase insertion, clause insertion and discourse insertion.

\section{1) Letter insertion}

The inserted English letter is usually the short form of a certain English word or phrase. In Case 1, an advertisement for the mobile phone, "3D", the short form of "three dimensional" is inserted into the Chinese slogan to form a Chinese phrase "3D 环绕音效 (three dimensional multichannel sound)". In Case 2, 5A is the short form of OA (office automation), BA (building automation), CA (communication automation), FA (fire automation), and SA (safety automation). Therefore, the letters inserted most often are the short form of some phrases that are usually technical terms in English. In this sense, letter insertion in this case is just a variation of word insertion and phrase insertion.

Case 1

独特虚拟 3D 环绕音效, 殹意享 MP3 的乐趣!

(Special virtual 3D multichannel sound, enjoy the pleasure from MP3!)

Case 2

星汇国际，倡导国际化办公模式，同步全球商务，以现代时尚建筑、领先物业形态、高档商务配套、5 智能系统等吸引诸多品牌企业进驻，催化珠江新城乃至大广州全新商业时代！

振业城

(Xing Hui International Corporation advocates internationalized office mode, keeps up with global business, and attracts big brands with modern and fashionable buildings, leading property management format, advanced business facilities and $5 A$ intelligent system, in order to boost Zhujiangxincheng and Guangzhou as well into a brand new business world!-Zhenye City)

2) Word and phrase insertion

Chinese advertising with English words and phrases inserted could be most frequently found in the data. $85 \%$ of 603 pieces of advertising contains word and phrase insertion. This result is quite different from the findings of Martin (2002, pp. 388-389), who concluded that advertisements containing single English words are rarely found in French advertising in France. After the data analysis, it is found that the inserted words and phrases could be of the following three kinds:

a. company name ("TCL" in Case 3; "Gol" in Case 4; "DELL" in Case 5) or product brand name("Dimension ${ }^{\mathrm{TM}} 2400$ " in Case 5);

English company name or brand name occur in 323 of the total 603 advertisements collected(54\%), most of which are names of foreign brands like Toyota, IBM, TNT, Anycall and DELL. But some are domestic company names, such as Lenovo and TCL. Although the Chinese versions of these brand names have been widely accepted by the public, the English versions are still preferred in advertising. A case in point is "TCL" in Case 3. Instead of “王牌” (Wangpai), the admen inserted TCL, the English form. Apart from company names, brand names or names of the model of product advertised, as in Case 4 and 5, is usually presented in English in Chinese newspaper advertising.

b. high-tech term ("IT", "CD" and "MP3" in Case 5);

c. pop word ("high" and "show" in Case 5) and others ("DJ" in Case 5).

A long list of small English pop words have been found in data as inserted English, especially in the slogan, like "hot", "cool", "in", "OK", "party", "fans", "kawaii", "hit", "PK", and "DIY". Some of them have got the well-accepted Chinese equivalence. For example, “COOL" could be perfectly translated as “酷” (cool) and “粉 丝" (fans). Even though, the English is used instead of the Chinese translation.

Case 3

坚持是金 TCL 钛金空调

(Persistence is golden TCL Titanium Air conditioner)

Case 4

$\mathrm{Gol}$ 旋彩 旋出生活新色彩

(Gol Xuancai Show the New Color of Life)

Case 5 
DELL

你身边的 IT 专家

听音乐，做 CD，我的 Dell ${ }^{\mathrm{TM}}$ Dimension $^{\mathrm{TM}} 2400$ 满足我 !

有做 DJ 的机会就尽情的 show，你的音乐才能会因为有了 Dell $^{\mathrm{TM}}$ Dimension $^{\mathrm{TM}} 2400$ 而大放异彩，...... 把 MP3 发送到您的环绕立体声系统中, 享受喜爱的音乐, 烧录自己的 CD , 尽情的 high 吧 !

(DELL

The IT Specialist Beside you

Listen to music, burn CD, my Dell ${ }^{T M}$ Dimension $^{T M} 2400$ satisfy me!

Just show as you like if you have an opportunity to be a DJ, in which way your music will sprout out because you have Dell ${ }^{T M}$ Dimension ${ }^{T M} 2400$,...send MP3 to your multichannel sound system, enjoy your music, burn your CD, get high!)

3) Clause insertion

In the data with clause insertion, the inserted clause occurs as an advertising slogan either at the first beginning of an advertisement as in Case 6 or at the final end as in Case 7 or both as in Case 8. And this pattern is frequently identified in advertising discourses of automobiles, mobile phones and real estate.

Case 6

Panasonic

ideas for life

辉煌还是黑暗?

未来在你一念之间。

珍惜电力资源, 请选择高能效空调！

(Panasonic

ideas for life

Glory or darkness?

The future is decided in flash.

Cherish electricity resources, and please choose high-efficiency air conditioner!)

Case 7

新世界中国地产

Dreams Come True

成就万千梦想

缔造优质物业 成就万千梦想

新世界, 致力打造优质物业, 成就万千美好梦想!

(New World China Real Estate

Dreams Come True

Realize thousands of dreams

Develop high-quality property management and realize thousands of dreams

New World, aims to develop high-quality property management and realize thousands of dreams!)

Case 8

T IS POWER.

澎湃动力, 御驾独尊。

THE VOLVE S80 2.5T, 让您赢得稀有成就的全新力量。......Volvo S80 2.5T 震撼驾势, 给您万般尊崇的超 凡成就体验。

Volvo

for life 


\section{Great momentum , Your special car}

THE VOLVE S80 2.5T gives you a new power to attain great achievement. ......Volvo S80 2.5T gives you an extraordinary driving experience of extraordinary achievement.

Volvo

for life)

\section{4) Discourse insertion}

Discourse insertional code-mixing refers to the insertion of one discourse in one language or dialect into another discourse of a second language or dialect. In Chinese advertisements collected, basically the matrix language is Chinese and the inserted one is English. This type of insertion occurs mostly in real estate ads and want ads.

Case 9

\section{英伦名苑 3 期 \\ 历久弥香，沉醉一段英伦梦想}

You can choose to sleep deeply in an afternoon full of sunshine, listening to chatter flowing through that British style cloister, dreaming yourself to become a beautiful England butterfly......

\section{侨西城-醇正英式社区}

\section{一次造逅，倾心永远}

(

Yinlunmingyuan Phase 3

With a longer history, indulge into a dream of England

You can choose to sleep deeply in an afternoon full of sunshine, listening to chatter flowing through that British style cloister, dreaming yourself to become a beautiful England butterfly......

Qiaoxicheng $\cdot$ Real England-style community

Once experience will give you life-long love.

In Cases 9, a more detailed description in English is inserted, following the concise Chinese version, complementing it with exoticism.

\subsubsection{Alternation}

According to Muysken, alternational approach views the constraints on code-mixing in terms of the compatibility or equivalence of the languages involved at the switch point. From this perspective, code-mixing is akin to the switching of codes between turns or utterances. In Chinese newspaper advertising, alternational pattern usually occurs in the form of Chinese-English equivalence, i.e. two distinct codes carrying the same meaning. What's worth mentioning is that in Chinese advertising very often the Chinese term is introduced first, followed by the English equivalence. This pattern contributes to the consumers' easy understanding of the key information.

Case 10

\section{上海浦东发展银行}

Shanghai Pudong Development Bank

\section{广州分行}

Guangzhou Branch

\section{热情周到}

Enthusiastic and Satisfactory

\section{优质服务}

High Quality and Efficiency

技术服务

Advanced technology

安全快捷 


\section{Security and Speed}

This advertisement aims at publicizing Guangzhou Branch of Shanghai Pudong Development Bank. From the very beginning to the end, there is one-to-one relationship between Chinese and English.

\section{Function Analysis}

According to Verschueren (1999), using language must consist of the continuous making of code choices, consciously or unconsciously, for language-internal and language-external reasons. Code-mixing is such a typical manifestation of code choice. And compared with other instances of language use, code-mixing is highly motivated and the intentionality involved in the performance is evident because it is often utilized by language users to realize some specific goals which cannot be approached through the employment of only one language or language variety. In this section, Markedness Theory will be used to explain how Sino-Anglo code-mixing contributes to persuasiveness of advertising language. Based on some relevant discussions of the previous researchers, the writer will explore textual and contextual functions of Sino-Anglo code-mixing in Chinese newspaper advertising discourse from a more comprehensive perspective.

\subsection{Textual Effect}

\subsubsection{Semantic Effect}

Gumperz (1982, p. 93) argues that code-mixing is more than a way of contrastively emphasizing part of a message; it contains a semantic value. When it comes to Sino-Anglo code-mixing in Chinese advertising, mixing English in Chinese advertising fulfils semantic functions as lexical gap filling. Since most foreign companies' names, technical terms and pop words have not received well-established translations in China, to use the original English ones will better fill the lexical gap and avoid confusion that different translations may result in. And under some other circumstances, English is used in advertising as a better choice of code when no appropriate or equivalent expressions can be found. For example, "hot" and "in" inclusively means very popular, cool and fashionable in English, while in Chinese we can hardly find one equivalent word. Besides, on certain occasions and topics, it is more convenient and explicit to use conventionalized English abbreviations instead of the Chinese translation. "IT", "CD", "DJ" and "MP3", as terms in science and technology, are abbreviations of information and technology, compact disco, and disco jockey. Topic of science and technology needs particular terminology for exactness of information and convenience of expression, and therefore it is actually very common for these terms to occur in English rather than in Chinese because topics are closely linked with the international market and thus the international language "English" is used here to make the expressions more exact and appropriate. These proper name, concrete nouns and technical terms help present hard facts and bridge the information gap. English makes the wording more precise and concise.

\subsubsection{Rhetoric Effect}

1) Rhyme

Sometimes copywriters prefer to use English letters or words to make the slogan rhymed, which may add to persuasiveness of advertising language. As stated previously, the slogan “我的 Life. 随时 Live” ("Make my life live at any moment")in Case 11 makes the whole discourse more memorable since the English words inserted make the whole sentence rhymed.

Case 11

我的 Life. 随时 Live.

("Make my life live at any moment")

\section{2) Alliteration}

Alliteration refers to the appearance of the same initial consonant sound in two or more words, such as "clean and clear". It is often used to give emphasis to words that are related to meaning. In case 12, two alliterations "Digital - Delight" and "Live in Love in" make the two slogans memorable. For the first one, the Chinese version “数字家园. 快乐无限” (A digital garden · unlimited pleasure) by itself cannot make it. Similarly, if the adman just uses “居住其中，乐趣无穷” (If you live in it, you will love it) instead of “Live in Love in”, the piece of advertising will become less impressive.

Case 12

$$
\begin{aligned}
& \text { Digital · Delight } \\
& \text { 数字家园. 快乐无限 }
\end{aligned}
$$


Live in Love in

2005 幸福升值年

活得更好

\author{
Digital · Delight \\ A digital garden $\cdot$ unlimited pleasure
}

Live in Love in

2005 Happiness Rocketing

A Better Life

3) Pun

In insertional Sino-Anglo code-mixing in Chinese newspaper advertising, a bilingual pun is a very interesting phenomenon. The phenomenon that an English expression which is homophonous with a Chinese target morpheme is punned into a Chinese syntactic frame is referred to as a bilingual pun. It is a rather interesting way to enrich the meaning of monolingual advertisements. Sino-Anglo puns are tightly constrained formally in that they require a highly conventionalized linguistic structure. And they are highly motivated semantically, rather than being based on random exploitation of homonymy. A majority of puns in the writer's collection occur below the word level - a syllable of a Chinese word is replaced with an English letter or word. For example,

Case 13

相约在这里, e 网情深

(Have a date here, and the e-net will give you a passionate affection.)

In case 13, “e” inserted in the Chinese idiom “一往情深” (a passionate affection) can present the slogan in two ways. The first comes from the idiom “一往情深” (a passionate affection) which goes well with the dating program advertised. It implies this program gives you a platform for enjoying sweet dating and love. The second one is thus a profile of this program since it works through electronic communication and network.

Case 14

摩托罗拉时尚广告 phone 行天下

(Like Motorola fashion ads, the phones are found everywhere)

In Case 14, “phone” is consonant with “风 (feng)” in Chinese. In Chinese, “风行天下” (popular) can create the image of something widespread in large quantities and something enjoying high popularity. Thus the English word punned "phone" appearing in this advertisement indicates that the mobile phone is very popular, just like the wide-spread advertisement. With the English word "phone" inserted, the advertisement can kill the bird with one stone-gives prominence to popularity of Motorola phones as well as the advertisements.

To sum up, bilingual pun in Chinese newspaper advertising works perfectly for the advertising purpose- to attract attention, to arouse interest and more importantly, to make the product as well as the advertisement deeply carved in the consumers' mind, which is the core of persuasiveness of advertising language.

\title{
5.2 Contextual Effects
}

\subsubsection{Construction of Identity through Activation of English Schema}

Languages, other than conveying linguistic meanings, also carry with them extra linguistic messages. For example, certain values and social and historical background are usually attached to each language. Hence, language comes to be associated with particular attitudes or beliefs. This is what Markedness Theory indicates as "language schemas". These schemas include individuals' perceptions about the kind of people that speak a certain language, the situations and occasions when that language can be chosen, the topics for which the language is better suited, the beliefs of how the language may be perceived by others, and the meanings that may be communicated by choosing the language. Markedness Theory considers code choice as a way of communicating desired or perceived group memberships and interpersonal relationships. Markedness Theory explains the notion of language schemas (Luna \& Laura, 2000, p. 45), which are the sets of features or associations linked to a particular language. Certain codes or languages are associated with certain features, and speakers choose the language they will use by matching the language with the salient features of a particular 
event (Myers-Scotton, 1993b). In other words, an individual's choice of code signals a specific social identity. Code can be associated with specific meanings, and individuals can communicate those meanings through their code choices. For instance,

English — fashionable, modern, practical and confident lifestyle;

French —elegant, charming and romantic;

German —of high quality, industrial, and reliable;

Italian—good life as expressed through food;

Sanskrit—nationalism and traditionalism;

Arabian and Persian—something of Islamic background.

(Bhatia, 1992)

Mixing a foreign linguistic element into an advertisement may present consumers with a new language schema that is different from the previously activated language schema by the original language. In this sense, the mixed English words, phrases, sentences or discourses in Chinese newspaper advertising become marked and activate a different set of features associated with the English language - the English schemas. For instance, in the slogan of China Mobile in the promotion of M-zone, “心动 COOL 号,最 HIGH 的爱情表白” “"the most attractive cool phone number gives you the highest expression of love"), the mixed English pop words "COOL" and "HIGH" may activate the young consumers' association of fashion and romance from the English words in the Chinese context.

Explaining that mixing a foreign code activates language-specific associations, the writer argues that the aim of such language behavior in advertising copywriting is to construct identity of the advertiser and the potential consumers through activation of language schemas. Markedness Theory also suggests that individuals will mix other languages into their speech when they want to communicate certain social meanings or group memberships (Myers-Scotton, 1993b). A marked element is recognized by the parties involved in the exchange as communicating a specific intended meaning. In other words, it is linked to a specific identity through this specific form of code. Linguists have long understood that language signals social identity. Bakhtin pioneered the idea that linguistic meaning cannot be understood without reference to speakers' and hearer's identities (Piller, 2001, p. 158). In other words, linguistic meaning does not exist independent of identity. A lot of sociolinguists have also addressed themselves to the relationship of language and identity. "Language acts are acts of identity." (Le Page \& Tabouret-Keller, 1985, cited from Tabouret-Keller, 1997, p. 316). Language is taken as an external behavior, which identifies a speaker as a member of some group. Wardhaugh (2000, p. 110) claims that code-mixing allows speakers to assert power and express identities.

Based on all these assertions, the writer holds that code choice in advertising helps accomplish this task of constructing identities from two aspects: firstly, the copywriters use English to exhibit the advertisers' identity by activating its schemas; secondly, the copywriters accommodate the audience's psychology of belonging to a certain group or preserving certain kind of identity. Advertising is such an approach to gain this aim of identity construction or adaptation through the activation of language-specific associations.

Advertising helps us to make sense of things. It validates consumer commodities and a consumer life-style by associating goods with personal and social meanings and those aspirations and needs which are not fulfilled in real life. We come to think that consuming commodities will give us our identities. (Dyer, 1982, p. 185)

Identities are established through the inserted English technical terms, brand names or company names, and English idioms. In fact, after analysis of a large quantity of advertisements, the writer finds that slogans or headlines that accompany the brand name or at the end of the body copy are better meant to encapsulate the identity or philosophy of a brand. Their status as an identity marker is also reflected in the fact that they often enjoy the same legal protection as the brand name and the trademark. Therefore, the language used in the slogan of an advertisement becomes the advertisement's "master voice" - the voice that expresses authority and expertise.

However, it is important to note that these associations are not necessarily with native speakers and the cultures of native English-speaking countries. The use of English has become a symbol of internationalism during the process of globalization. With wide use of English as a world language, English is indeed not used to link with an ethno-cultural stereotype of any specific English-speaking country, but a social stereotype-cosmopolitan identity for the products in most case. English is a symbol of a global being. Everyone wants to be perceived as a 
global competitor, and such a perception is best achieved through the use of English. The writer claims that it has become associated with a certain segment of Chinese society as it appears through advertising discourses: highly efficient cosmopolitan business elite and the future-oriented, pun-seeking and romance-loving city dwellers that enjoy good things in life. Such identity of consumers has been summarized from the selected advertising slogans in the data.

\subsubsection{Mixing English to Screen Out the Target Readers}

In some want ads for multinational corporations, the copywriters always employ code-mixing not only to imply advertisers' identities as a global competitors, but more importantly and practically, to hunt for the qualified personnel.

The mixed English discourse in Chinese want ads indicates requirement for good command of English from the potential candidates. Therefore code-mixing is not just a symbol of the identity of the company - a modern and internationalized corporation, but more importantly, is a sieving machine, which aims to select most competent and appropriate person for this vacancy. The reason why some job vacancies are in English while others are not is that more often English proficiency is a must to some jobs while at other times it is not necessarily asked for. In this way, code choice helps differentiate the requirements for English proficiency.

\subsubsection{Mixing English to Mitigate the Tone with Consumers through Euphemism}

In Chinese advertising discourses, some English expressions are used out of such purposes as saving the face of the potential consumers or softening the tone in the expression. In this sense, some English words or phrases for euphemism are inserted in Chinese advertisements. Euphemism is the substitution of a mild or vague expression for a harsh or unpleasant one. When it comes to a topic which sounds awkward or inconvenient to begin, the inference of a foreign code, as a way of indeterminate and ambiguous reference can help to soften harsh reality and mitigate the atmosphere. Unconsciously, it will shorten the distance between the consumers and advertiser. In this sense, English is a wise choice. As an indirect communication mode, mixing English as a substitute for certain Chinese expressions serves to improve the relationship between producers and consumers.

A case in point is the inserted English word "ED" in Case 15. It is the short form of "Erectile Dysfunction" with the Chinese translation “勃起功能障碍”. If this information is stated directly in Chinese, it will undoubtedly arouse the consumers' embarrassment and antipathy.

Case 15

深圳福华中西医结合医院

Shenzhen Fuhua I.T.W.M Hospital

孕育摇篮 缔造生命

可控的 $\mathrm{ED}$ 数码诊断治疗仪

(Shenzhen Fuhua I.T.W.M Hospital

Cradle for Life, Beginning of Life

Controllable ED digital therapy machine)

\section{Other Discussions}

\subsection{Why is English the Mixed Foreign Code?}

English, as the most widely used language in the world, undoubtedly, plays an indispensable role in people's communication. Because of its close relationship and attachment to economy, code in economically advanced countries and regions tends to be more advantageous and superior to that of the less developed countries and regions. Therefore, English, as its close tie with high fast-developed economy and high-technology is of the top priority. As mentioned in World Englishes model, English is the foreign language in China. Although the language proficiency cannot be comparable to that of Chinese, English in China still enjoys a much more prestigious position than any other foreign language. More and more chances and opportunities are offered to those who are in good command of English. Under such circumstances, it is quite easy to explain why there exists Sino-Anglo code-mixing in Chinese adverting. It could be more persuasive to be interpreted from the interactional relationship of social code choice and personal code choice (Guo, 1999). That is to say, when 
Chinese authority accepts, regulates and popularizes one code, the persons in this society would tend to choose this code in certain appropriate situations. And vice verse.

\subsection{Which Pattern of Sino-Anglo Code-Mixing Occurs Most Frequently? In Which Part of an Advertisement? Why?}

English mixed into Chinese advertising in the form of word or phrase is the most commonly seen type in Chinese newspaper advertising in the data collected. (Note 2) The positions in which the mixed English occurs most frequently are headlines or slogans that accompany the brand name at the first beginning or at the end of an advertisement and the technical terms inserted in the body copy.

Firstly, China is in the expanding circle of World Englishes Model, which indicates that English is taught and learned as a foreign language and the general English proficiency of the whole nation cannot be comparable to those in the outer circle and inner circle, though English is gaining influence and the number of English learners in China is increasing rapidly. Therefore, the acceptability of mixing long discourses is questionable. Secondly, the insertion of a headline or a slogan just after the brand name at the very beginning or at the end of an advertisement contributes to the identity construction in the Chinese advertising discourse as above.

\section{Conclusion}

The present article reports a research which exams Sino-Anglo code-mixing in Chinese newspaper from a sociolinguistic perspective. The writer offers a modified paradigm of code-mixing types on the basis of Muysken's model for typolgoy and explores the functions of code-mixing based on Myers-Scotton's Markedness Theory from two levels - textual and contextual levels with an eye to the nature of advertising language-persuasiveness. It is found that in Chinese advertising, there are insertional code-mixing and alternational code-mixing, with the former claiming the vast majority among the collected data. The inserted English are in the form of letters, words and phrases, and clauses; the alternational pattern is a paralleled Chinese-English format. Among all these lexical-grammatical patterns, word-and-phrase insertional code-mixing is the most frequently one, for English is only a foreign language in China. And thus the acceptability and proficiency of English in mainland China is not high enough to embrace too much English. From textual perspective, the mixed English occurs as letters, words and phrases to bridge the information gaps in Chinese advertising discourse; or compose rhyme, alliteration and puns to add to the impressiveness of the advertising discourse; from contextual perspective, the mixed English help to build up a global image of the advertisers and possible consumers, work as a screen machine to select the most qualified personnel and mitigate the tone with consumers through euphemism. All these textual and contextual functions can be subsumed into working for persuasiveness of Chinese advertising. As for the correlation of position of mixed English and function, it is possible that inserted English letters, words and phrases, and even clauses as slogans or brand names at the beginning or the end of the advertisements and alternational code-mixing works better as an identity indicator, while those inserted English discourses in want ads are more often taken as a screen machine to select the personnel with high English proficiency. And a few inserted English abbreviations in Chinese advertising can protect the consumers' face by avoiding the direct and explicit Chinese expressions that may hurt the consumers' feelings.

The findings contribute to the win-win situation of copywriters and sociolinguists. Firstly, Sino-Anglo code-mixing used in Chinese newspaper advertising illustrates that advertising is an unusually rich source of linguistic data which deserves special consideration and further exploration. Code-mixed advertisements provide a faithful and dynamic reflection of language contact and culture contact. Code-mixing in advertising makes linguists realize that the property or nature of language can be embodied and revealed from advertising, especially, from the mixing of codes in advertising. Apart from this, sociolinguists could get the trace of language contact and change from the most dynamic media and thus offer suggestions to the language policy makers. Secondly, the admen could get hints from the cases of Sino-Anglo code-mixing as regard to what should be mixed and how it is inserted in copywriting for different purposes. They could get enlightenment from the present study on how to use Sino-Anglo code-mixing as a verbal strategy for persuasiveness of advertising language.

\section{References}

Bhatia, T. K. (1987). English in Advertising: Multiple Mixing and Media. World Englishes, 6, 33-48. http://dx.doi.org/10.1111/j.1467-971x.1987.tb00175.x

Bhatia, T. K. (1992). Discourse functions and pragmatics of mixing: advertising across culture. World Englishes, 11, 195-215. http://dx.doi.org/10.1111/j.1467-971x.1992.tb00064.x 
Bokamba, E. G. (1989). Are There Syntactic Constraints on Code-mixing? World Englishes, 8, 277-292. http://dx.doi.org/10.1111/j.1467-971x.1989.tb00669.x

Dyer, G. (1982). Advertising as Communication. London: Methuen.

Fasold, R. W. (1984). The sociolinguistics of society. Oxford: Basil Blackwell Ltd.

Gumperz, J. (1982). Disourse Strategies. London: Cambridge University Press.

Guo, X. (1999). Chinese Sociolinguistics. Nanjing: Nanjing University Press.

Haarmann, H. (1984). The Role of Ethnocultural Stereotypes and Foreigh Languages in Japanese Commericals. International Journal of the Sociology of Language, 50, 101-221. http://dx.doi.org/10.1515/ijsl.1984.50.101

Haarmann, H. (1986). Verbal strategies in Japanese fashion magazines-a study in impersonal bilingualism and ethnosymbolism. International Journal of the Sociology of Language, 58, 107-121. http://dx.doi.org/10.1515/ijsl.1986.58.107

He, A. P. (1992). Linguistic Features and Cultural Functions of Sino-Anglo Code-mixing. Modern Foreign Languages, (1), 7-10.

He, Z. R., \& Yu, G. D. (2001). Researches on Codeswitching. Modern Foreign Languages, (1), 85-95. $\mathrm{http}: / / \mathrm{dx}$. doi.org/10.3969/j.issn.1003-6105.2001.01.009

Huang G. W. (2001). Theory and Practice of Discourse Analysis: A Study of Advertising Discourse. Shanghai: Shanghai Foreign Language Education Press.

Li, D. C. S. (2000). Cantonese-English code-switching research in Hong Kong: a Y2K review. World Englishes, 19, 306-322. http://dx.doi.org/10.1111/1467-971x.00181

Lü, D. R., Huang, G. W., \& Wang, J. (2003). A Systematic Functional Study of Code-switching. Foreign Languages and Their Teaching, (12), 6-11. http://dx.doi.org/10.3969/j.issn.1004-6038.2003.12.002

$\mathrm{Lu}$, J. (1991). Code-switching Between Mandarin and English. World Englishes, 10, 139-151. http://dx.doi.org/10.1111/j.1467-971x.1991.tb00147.x

Luna, D., \& Laura, A. P. (2005). Sociolinguistic Effects on Code-switched Ads Targeting Bilingual Consumers. Journal of Advertising, 34, 43-56. http://dx.doi.org/10.1080/00913367.2005.10639196

Martin, E. A. (1998). Code-Mixing and Imaging of America in France: the Genre of Advertising (Unpublished doctoral dissertation). University of Illinois at Urbana-Champaign.

Martin, E. A. (2002). Mixing English in French Advertising. English Today, 18, 375-402. http://dx.doi.org/10.1111/1467-971x.00256

Muysken, P. (2000). A Typology of Code-mixing. Cambridge: Cambridge University Press.

Myers-Scotton, C. (1989). Code-switching with English: types of switching, types of communities. World Englishes, 8, 333-346. http://dx.doi.org/10.1111/j.1467-971x.1989.tb00673.x

Myers-Scotton, C. (1993a). Duelling Languages: Grammatical Structure in Codeswitching. Oxford: Oxford University Press.

Myers-Scotton, C. (1993b). Social Motivations for Code-switching. Oxford: Oxford University Press.

Piller, I. (2001). Identity Construction in Multilingual Advertising. Language and Society, 30, 153-186.

Verschueren, J. (1999). Understanding Pragmatics. London, New York: Arnold.

Verstergaard, T., \& SchrØder, K. (1995). The Language of Advertising. UK: Basil Blackwell Publisher Ltd.

Wang W. Q. (2013). A Probe into the Ads with Mixed Codes from the Perspective of Markedness Model. Journal of Nanjing Normal University (Social Science Edition), (6), 151-157. http://dx.doi.org/10.3969/j.issn.1001-4608.2013.06.018

Wardhaugh, R. (2000). An Introduction to Sociolinguitics. Beijing: Foreign Language Teaching and Research Press.

Yang, Y. H. (2008). Research into Code-mixing in Advertising Language. Foreign Languages in China, (3), 34-37. http://dx.doi.org/10.3969/j.issn.1672-9382.2008.03.006

Ye, X. L., \& Qin, X. B. (2004). A Study of Sino-Anglo Code-mixing and its Causes in Guangzhou Press Advertising. Journal of South China University of Technology, (6), 58-63. 


\section{Notes}

Note 1. Each unit is treated as a piece of discourse made up of five parts-product and company name; headline and slogan; signature line and logo; product label; and body copy.

Note 2.The number of it amounts to 512, accounting for $84.9 \%$ of 603 of the total number.

\section{Copyrights}

Copyright for this article is retained by the author(s), with first publication rights granted to the journal.

This is an open-access article distributed under the terms and conditions of the Creative Commons Attribution license (http://creativecommons.org/licenses/by/3.0/). 